\title{
Role of Legal Practitioners in the Environmental Protection of Anambra State: A Wake up Call
}

\author{
Anthony Okoye (PhD) \\ Department of Environmental Management, \\ Nnamdi Azikiwe University, Awka, Nigeria \\ doi: 10.19044/esj.2017.v13n20p251 URL:http://dx.doi.org/10.19044/esj.2017.v13n20p251
}

\begin{abstract}
The environmental challenges facing the state are numerous. In terms of the prioritization, erosion and waste management are of high priority, flooding and deforestation have medium priority while industrial pollution and biodiversity loss have low priority. State has environmental laws, but they cannot be meaningfully helpful unless their effective implementation is secured by the efforts of enforcement agencies and lawyers who deliver environmental justice. Unfortunately, lack of exposure to environmental law by members of the judiciary and most legal practitioners in the state hinders its proper implementation. The sample for this study was 121 participants drawn through convenience sampling technique. This consists of 25 legal practitioners, 25 environmentalist and 71 others from different professional areas. The instrument for data collection was a 22-item questionnaire which was made up three parts. While the legal practitioners were of the opinion that they are doing their best, the result revealed that both the environmentalists and other professionals who need the services of the legal practitioners rated their performance to be very low. Appropriate training and awareness programmes are therefore recommended so that lawyers would be better grounded to discharge this onerous duty in the state.
\end{abstract}

Keywords: environmental challenges, legal practitioners, training, awareness programme,

\subsection{INTRODUCTION}

Anambra state like every other state in Nigeria continues to urbanize with its attendant population explosion and industrialization. The state is characterized by the presence of more than 2 million residents who throng from other parts of the country into the state seeking for greener pastures. This shift of human migration has posed problems to the State's resources, environmental sanitation, infrastructure and others. There are three major 
urban centres in the state namely; Awka, Onitsha and Nnewi. The State capital is Awka while Nnewi is the industrial centre and Onitsha the commercial centre with the largest market in the West African sub-region. Nnewi is popularly referred to as "The Japan of Africa" because of the large scale fabrication of machines, machine tools, motor parts and accessories etc. This development increases exponentially the number of people that move in and out of the state on daily basis with its attendant environmental disturbances.

The environmental challenges facing the state may include; erosion, poor municipal solid waste management, flooding, indiscriminate faecal waste disposal, poor disposal of liquid waste especially from industries aggravating soil and water pollution, poor public environmental awareness, proliferation of illegal structures, deforestation and other global contemporary environmental challenges of which activities from Anambra state contributes to like global warming, ozone layer depletion and acid rain. An overall assessment reveals that government has not made adequate effort to tackle the environmental problems of the state.

The environment cannot speak for itself. People are impacted inevitably when the environment is hurt. If the ethical duty of the lawyers simply put is to protect people, it implies that environmental protection is indirectly part of the ethical duties of the lawyers. Hence, the lawyer's efforts and courts positive response to environmental problems can have significant attitudinal change amongst polluters for environmental protection. In Anambra state, the investigation conducted by the author revealed that only about $2 \%$ of the legal practitioners are environmental lawyers and most of them were not originally trained in that field. This implies that the major roles of lawyers which include delivery of environmental justice, encouragement of citizens to institute legal actions against polluters, advocate for new policies related to environmental protection, provide mentorship opportunities to junior Lawyers would be difficult to be achieved. This paper seeks to address two fundamental questions which include: what roles legal practitioners are expected to play in the environmental protection of the state and the extent to which they perform these roles for the sustainable management and protection of Anambra State's environment.

\subsection{THE ENVIRONMENTAL PROBLEMS AND SUMMARY OF THEIR CAUSES}

In terms of the prioritization of the environmental issues of Anambra State, erosion and waste management are both of high priority while flooding and deforestation have medium priority and then industrial pollution and biodiversity loss have low priority. The major challenges and their respective causes are highlighted below. 


\section{EROSION}

In Anambra State, erosion has become the most common scenery and the state presents the most typical features of erosion in the country (Egboka, 2009). Gully erosion is either naturally or anthropogenically induced. Gully erosion is the terminal phase of a four-stage erosion process involving splash, sheet, rill and gully (Amangabara, 2012). The process begins by water falling as rain drops and flowing on the soil surface. Splash erosion results when the force of raindrops falling from the bare or sparsely vegetated soil detaches soil particles. Sheet erosion occurs when these soil particles are easily transported in a thin layer or sheet by flowing water. If this sheet runoff is allowed to concentrate and gain velocity, it cuts rills and gullies as it detaches more soil particles. As the erosive force of flowing water increases with slope length and gradient, gullies become deep channels and gorges (Amangabara, 2012). Thus, nature of the topography and the type of soil of the state are the major natural factors that cause gully erosion in Anambra State. Anthropogenic causes include urbanization which comprises road construction and building developments, farming, uncontrolled grazing, deforestation and mining activities. Bad drainage/culverts of badly constructed roads in the state contribute immensely to gully erosion. Gullies tend to form where the concrete lined drains and culverts are too small to accommodate peak surface runoff. Again in most of the poorly constructed roads, the culverts are not terminated at base of slope locations and are allowed to decay and become clogged with debris. The overflowing water erode beneath the road side gutter or culvert which eventually falls away to provide a site of localized erosion (Amangabara, 2012). By the accumulation of large quantities of water or by gradual deepening, rills and erosion gullies of various sizes comes into being. In another case, the culvert outlets are not armored and so the erosion at the invert of the culvert create a waterfall that increases the energy potential of the channel concentrated flow (Amangabara, 2012).

Moreover, most sand mining sites in the state eventually develop into huge gullies as rainwater continues to impact on them. Uncontrolled grazing and deforestation expose the top soil to erosion as exposed soil is no longer capable of resisting the erosive actions of the rainwater

\section{SOLID WASTE MANAGEMENT}

Poor Municipal solid waste management is another major environmental problem in Anambra State. For several years now, government has been making ineffectual attempt to solve waste management problems in the state due to lack of political will to take the firm decision needed to save the state from this menace (Okoye, 2016). Worse still, there has been a wide spread apathy among Anambrarians on issues pertaining to 
waste management. This has aggravated the waste management problem of the state. Hence there is an urgent need for responsibility sharing and citizen participation in solid waste management in the state, the first step being having government display the needed political will. The major causes of the problems currently are highlighted below.

1) Confusion: Waste management related duties including contracts are delegated to various governmental functionaries, which is a symptom of inevitable collapse of waste management department of the environmental sector. This has indeed caused a serious confusion and malfunctioning of the parastatal. In other words, ASWAMA Boss does not direct any longer which implies that he cannot enforce the ASWAMA law.

2) ASWAMA turned to AWAMA: Government in several occasions has restricted Anambra State Waste Management Authority (ASWAMA) to function only in Awka thereby making it Awka Waste Management Authority (AWAMA). With this, government should scrap ASWAMA if she feels that there is nobody that is competent enough to direct the affairs of the parastatal in the state otherwise why restrict them to Awka.

3) Vested Interest: A lot of politicians, civil servants, few senior government officials and other stakeholders are much interested in solid waste management not necessarily to keep the state clean but to make money without solving the problems. Hence, there are too many wolves some of whom are supported by the government to ensure that nothing works in this sector by allowing them to carve their own niche to make money from people for doing nothing, all in the name of sanitation and waste management.

4) Inadequate Waste collection coverage: The contractors and ASWAMA staff that collect wastes all through the cities do so in areas where they have their receptacles placed. This compels people who are not served because of the absence of receptacles to either dispose them indiscriminately or to carry them with their vehicles only to dump them along the streets when they come into town

5) Poorly maintained Dump site: Due to the terrible nature of the makeshift dumpsites, trucks get stuck and this delay disposal of waste as other trucks with waste would always stand by until the stuck truck is pulled out. The streets will be adorned with wastes no matter the efforts if there are no easily accessible dumpsites to dispose these wastes. Besides, the dumps are not promptly pushed

6) Poor Enforcement and litigation: Enforcement is the key to sustainable waste management especially in developing countries. No matter the money you spend and efforts you make, the streets would 
still look dirty without enforcement as people would often prefer to leave empty receptacles and dump on ground, drop refuse anywhere, burn their waste and also refuse to pay their sanitation levies. Anambra State Waste Management Authority currently do not take people to court presently as provided by the Law, rather in most cases they seize the properties of the weak ones and extort money from them.

7) Insufficient trucks and receptacles to allow for efficient cleanliness: The receptacles distributed in the city are not enough to allow for proper city cleanliness. Thus, pockets of illegal dumps are seen along most streets as people cannot find a place to conveniently dispose their waste

8) Poor public attitudinal behaviour: During rainfall, people dispose of their wastes into the drain which block the drains, dirty the roads and pollutes the receiving water body. Besides, people hardly pay their sanitation levies as most strongly believe that it is the duty of government to dispose of their wastes. It is expected that all segments of the society must team up with ASWAMA to find a sustainable solution to urban solid waste management but instead all are out to spoil the work and enrich themselves at the state detriment.

9) Weak Leadership: Despite the fact that the current MD/CEO is trying the much he could being a novice to the field, there are too many committees, contractors, and controller's currently managing waste with little or no control from the parastatal. There is need for a strong passionate professional at the center to bring innovations that would help to drive the process of waste management in Anambra State. It has been a very difficult task for government to appoint a passionate professional to solve the problem or to give support to the ones appointed.

\section{FAECAL SLUDGE MANAGEMENT}

Government has been making little efforts to tackle the solid waste problem which is however still at the lowest level of moving waste from the street to the dumpsite, but, no one in the state including the government has made any serious effort to come up with any idea on how to map out a place to dispose of the feacal sludge in environmentally friendly manner let alone a way to manage it so that it will not cause any health hazard.

Feacal sludge of a community contains the complete spectrum of enteric pathogenic microorganism excreted by the community, which is a function of the endemic disease rates prevalent in that community. In addition to pathogenic bacteria, such as the agents of such diseases of typhoid fever and cholera, night soil may contain enteric viruses of such 
diseases as poliomyelitis, infectious hepatitis and numerous other diseases caused by enteric viruses.

In the urban cities in the state, the night and septic sludge is collected by private companies using trucks with vacuum pump for septic tanks. They dump these wastes in various places mainly in the bush, water bodies and gullies. When rain falls, these enteric pathogenic microorganisms are carried to other places which in most cases end up in the water bodies. This constitutes a very serious environmental and health hazard.

\section{FLOODING}

The severe impact of flood whether it happens as a result of climate change or otherwise is most likely to be in urban areas where people, resources and infrastructure are concentrated (Arambepola, and Iglesias 2009). Aside from the unusual rain that has been experienced recently, that has contributed to flooding, the cause of flooding as noted by the stakeholders may also include lack of adequate drainage facilities to collect the storm run-off for safe disposal, ineffective planning regulations which either ignore or condone the illegal erections of buildings and other structures on flood plains, the unhealthy dumping of all sorts of solid wastes in the usually open channel drainage systems, use of concrete in landscaping without providing proper drainage channels and lack of coordination of the relevant ministries.

\section{NDUSTRIAL POLLUTION}

Industries are springing up at an alarming rate in the state especially in the urban centres. Unfortunately, most of these companies did not do their Environmental Impact Assessment prior to their establishment. Their effluents are discharged without any meaningful treatment and in most cases they are discharged raw without any form of treatment. In most cases, most villagers do not know the health implications of these industrial activities otherwise they would surely cry out and compel the industrialists to conform to the norm. The industrialists in most cases do not know the full implication of their activities in the host community. This, if not confronted would cost the state a fortune in no distance time

\section{DEFORESTATION}

Anambra State falls within the rain forest region. Trees are the highest source of fresh air and major scavenger of carbon dioxide which is one of the major global warming gases. Trees protect and stabilize soils and protect it from erosion. The clearing of forests for agricultural activities, logging and fuel wood collection has exacerbated deforestation. A general 
assessment reveals that Anambrarians have not imbibed the culture of replanting trees when they cut them for any purpose.

\subsection{THE ROLE OF LEGAL PRACTITIONERS IN PROTECTING THE ENVIRONMENT}

People are impacted inevitably when the environment is hurt. If the ethical duty of the lawyers simply put is to protect people, it implies that environmental protection is indirectly part of the ethical duties of the lawyers. Hence, the lawyer's efforts and courts positive response to environmental problems can have significant attitudinal change amongst polluters for environmental sustainability.

The Paragraph 8(26) of Agenda 21 states that "efforts to provide an effective legal framework for sustainable development should be oriented towards improving the legal-institutional capacities of countries to cope with national problems of governance and effective law-making, and law-applying in the field of environment and sustainable development.” This emphasizes the crucial role of the judiciary in protecting the environment (Shelton, and Kiss, 2005). The law is the instrument through which society is preserved, in its shape and character. Legal practitioners are not only to perform their traditional functions of catering to the professional needs of the society, of administering justice and manning the various legal institutions of the state but they must also be involved in social change, be committed to law reforms to ensure the harmonization of law with the culture of the people and they must strive to ensure strict adherence to the rule of law (Lawyers role in the society, 2017)

Environmental law is crucial for the protection of the environment which is our common home. The availability of environmental legislation cannot, on its own stop future environmental degradation rather full implementation and enforcement of the existing laws would help to conserve the environment. In other words, environmental laws, regardless of how "good" they might be may not be meaningfully helpful unless their effective implementation is secured. Unfortunately, lack of exposure to environmental law by members of the judiciary and most legal practitioners in the state hinders its proper implementation.

The major roles that Lawyers should play include;

- Delivery of environmental justice

- Encouragement of citizens to institute legal actions against polluters.

- Advocate for new policies related to environmental protection

- Provide mentorship opportunities to junior Lawyers 


\section{Delivery of Environmental Justice}

Lawyers play indispensible role in the mechanism of the administration of environmental justice. It is their duty to give the environment a strident legal voice. It is through litigation that courts enjoy their unique role in upholding the environmental rule of law. Environmental litigation can take many forms, including civil actions based on tort, contract or property law, criminal prosecutions, public interest litigation, or enforcement of constitutional rights (Shelton, and Kiss, 2005). In, Anambra State, most lawyers shy away from environmental litigations and face other forms of litigation due mainly to the fact that they are not conversant with the technicalities of environmental legislations. This has drastically reduced access to environmental justice resulting to incessant abuse of the environment. On the other hand, if more lawyers undergo the appropriate training, they would repeatedly win environmental cases that would encourage direct citizen legal action against individual or company polluters

\section{Encouragement of Citizens to Institute Legal Actions Against Polluters}

The advancement or improvement of environmental law by lawyers by creating environmental law awareness to the citizens on the implication of compliance and non-compliance would go a long way in improving the environmental status of the country. Ignorance of citizen's right and lack of knowledge of the environmental laws are the two major factors that incapacitate the citizens from challenging polluters who infringe on their environmental rights. However, if lawyers embark on such awareness campaign, people would know their rights and be willing to institute legal action against polluters of their environment.

\section{Advocate for new policies related to environmental protection}

Lawyers are in a good position to advocate for policies related to environmental protection due to their profession. They can easily with the help of environmentalists figure out the policies that would engender more stringent measures that would reduce environmental degradation.

\section{Provide Mentorship Opportunities to Junior Lawyers}

Most young environmental lawyers can work for environmental advocacy organizations, non-profit organizations or the government. Most fresh lawyers go into private practice, often times under an older legal practitioner. Most of these lawyers hesitate to go into environmental cases because they are not familiar with it. The few lawyers that venture into it are expected to groom some of their young lawyers in this area by giving them the necessary support needed to be well grounded in this area of jurisdiction. 


\subsection{METHODS}

The sample for this study was 121 participants drawn through convenience sampling technique. This consists of 25 legal practitioners, 25 environmentalist and 71 others from different professional areas.

The instrument for data collection was a 22 item questionnaire which was made up three parts. The first part sought information on the professional areas and highest educational qualification of the respondents. The second part of the questionnaire which had 10 items elicited information on the roles of the legal practitioners in environmental protection. The response format was based on 5-point likert scale, namely; strongly agree = 5 , Agree $=4$, Undecided $=3$, Disagree $=2$ and strongly disagree $=1$. The third part of the questionnaire contained 10 items which solicited information on the extent to which legal practitioners perform their environmental protection roles in the Anambra State. The response format was: very high extent $=5$, high extent $=4$, moderate extent $=3$, low extent $=2$ and very low extent $=1$. The questionnaire was duly validated by two legal practitioners and two environmentalists practicing in Anambra State. Its reliability was also established using split-half method. The reliability coefficients of the second and third parts of the questionnaire were 0.82 and 0.75 respectively.

\subsection{RESULTS}

The data collected was analyzed using mean. The following range of mean scores was used as decision rule on the extent of agreement/performance of the roles:

\section{For research question 1:}

1.00 - 2.59 Disagree

3.00 - 5.00 Agree

For research question 2:

$1.00-1.49=$ Very Low Extent

$1.50-2.49=$ Low Extent

$2.50-3.49=$ Moderate Extent

$3.50-4.49=$ High Extent

$4.50-5.00$ = Very High Extent.

Research Question 1

What are the roles of legal practitioners in environmental protection? 
Table 1: Mean responses on the roles of legal practitioners are expected to play in environmental protection

\begin{tabular}{|c|c|c|c|c|c|c|c|}
\hline & & \multicolumn{6}{|c|}{ Respondents' Profession } \\
\hline & & $\begin{array}{l}\text { Legal } \\
\text { Practitione } \\
\text { rs ( } \mathrm{n}=25)\end{array}$ & \multicolumn{2}{|c|}{$\begin{array}{l}\text { Environment } \\
\text { alists }(n=25)\end{array}$} & $\begin{array}{l}\text { Other } \\
(\mathrm{n}=71)\end{array}$ & \multicolumn{2}{|c|}{$\begin{array}{l}\text { Total } \\
(n=121)\end{array}$} \\
\hline & & $\begin{array}{l}\text { Mean } \\
\text { Remark }\end{array}$ & \multicolumn{2}{|c|}{$\begin{array}{l}\text { Mean } \\
\text { Remark }\end{array}$} & $\begin{array}{l}\text { Mean } \\
\text { Remark }\end{array}$ & \multicolumn{2}{|c|}{$\begin{array}{l}\text { Mean } \\
\text { Remark }\end{array}$} \\
\hline 1. & $\begin{array}{l}\text { Deliver Environmental } \\
\text { Justice to the people }\end{array}$ & $\begin{array}{l}5.00 \\
\text { Agree }\end{array}$ & 5.00 & Agree & $\begin{array}{l}4.29 \\
\text { Agree }\end{array}$ & 4.55 & Agree \\
\hline & $\begin{array}{l}\text { Encourage citizens to } \\
\text { institute legal actions } \\
\text { against polluters }\end{array}$ & $\begin{array}{l}5.00 \\
\text { Agree }\end{array}$ & 4.00 & Agree & $\begin{array}{l}4.14 \\
\text { Agree }\end{array}$ & 4.30 & Agree \\
\hline 3. & $\begin{array}{l}\text { Advocate for new } \\
\text { policies related to } \\
\text { environmental protection }\end{array}$ & $\begin{array}{l}4.50 \\
\text { Agree }\end{array}$ & 4.50 & Agree & $\begin{array}{l}3.43 \\
\text { Agree }\end{array}$ & 3.82 & Agree \\
\hline & $\begin{array}{l}\text { Provide mentorship } \\
\text { opportunities on } \\
\text { environmental law and } \\
\text { litigation to junior } \\
\text { Lawyers }\end{array}$ & $\begin{array}{l}5.00 \\
\text { Agree }\end{array}$ & 4.00 & Agree & $\begin{array}{l}4.00 \\
\text { Agree }\end{array}$ & 4.20 & Agree \\
\hline 5. & $\begin{array}{l}\text { Advocate for the } \\
\text { provision of } \\
\text { environmental court }\end{array}$ & $\begin{array}{l}4.00 \\
\text { Agree }\end{array}$ & 4.00 & Agree & $\begin{array}{l}4.00 \\
\text { Agree }\end{array}$ & 4.00 & Agree \\
\hline 6. & $\begin{array}{l}\text { Encourage the inclusion } \\
\text { of environmental law and } \\
\text { litigation in the law } \\
\text { curriculum }\end{array}$ & $\begin{array}{l}5.00 \\
\text { Agree }\end{array}$ & 4.00 & Agree & $\begin{array}{l}4.43 \\
\text { Agree }\end{array}$ & 4.45 & Agree \\
\hline 7. & $\begin{array}{l}\text { Provide appropriate } \\
\text { training to boost lawyers } \\
\text { competence in } \\
\text { environmental litigation }\end{array}$ & $\begin{array}{l}4.50 \\
\text { Agree }\end{array}$ & 5.00 & Agree & $\begin{array}{l}4.14 \\
\text { Agree }\end{array}$ & 4.36 & Agree \\
\hline 8. & $\begin{array}{l}\text { Encourage the public } \\
\text { interest litigation by } \\
\text { reducing the bottlenecks } \\
\text { in the locus standi }\end{array}$ & $\begin{array}{l}5.00 \\
\text { Agree }\end{array}$ & 4.50 & Agree & $\begin{array}{l}3.71 \\
\text { Agree }\end{array}$ & 4.09 & Agree \\
\hline 9. & $\begin{array}{l}\text { Enforce of constitutional } \\
\text { rights of the people as it } \\
\text { relates to environmental } \\
\text { sustainability }\end{array}$ & $\begin{array}{l}5.00 \\
\text { Agree }\end{array}$ & 4.50 & Agree & $\begin{array}{l}4.00 \\
\text { Agree }\end{array}$ & 4.27 & Agree \\
\hline 10. & $\begin{array}{l}\text { Create awareness of } \\
\text { environmental law among } \\
\text { the populace }\end{array}$ & $\begin{array}{l}4.50 \\
\text { Agree }\end{array}$ & 5.00 & Agree & $\begin{array}{l}3.86 \\
\text { Agree }\end{array}$ & 4.18 & Agree \\
\hline
\end{tabular}

Table 1 shows that all the 10 listed roles were perceived as roles the legal practitioner is expected to play in environmental protection. This is shown by the mean responses of the all the respondents which ranged from 3.82 to 4.55 which indicate that the respondents agree that the legal 
practitioner is expected to; deliver environmental justice to people, encourage citizens to institute legal actions against polluters, advocate for new policies related to environmental protection, among other roles. There is a general agreement among all the respondents that these are the roles of legal practitioner in environmental protection.

\section{Research Question Two}

To what extent do legal practitioners play their environmental protection roles in the state?

Table 2. Mean responses on the degree of the performance of environmental protection roles by the legal practitioner

\begin{tabular}{|c|c|c|c|c|c|c|c|c|}
\hline & & \multicolumn{7}{|c|}{ Respondents' Profession } \\
\hline & & \multicolumn{2}{|c|}{$\begin{array}{l}\text { Legal } \\
\text { Practitione } \\
\text { rs }(n=25)\end{array}$} & \multicolumn{2}{|c|}{$\begin{array}{l}\text { Environment } \\
\text { alists }(n=25)\end{array}$} & $\begin{array}{l}\text { Other } \\
(\mathrm{n}=71)\end{array}$ & \multicolumn{2}{|c|}{$\begin{array}{l}\text { Total } \\
(n=121)\end{array}$} \\
\hline & & \multicolumn{2}{|c|}{$\begin{array}{l}\text { Mean } \\
\text { Remark }\end{array}$} & \multicolumn{2}{|c|}{$\begin{array}{l}\text { Mean } \\
\text { Remark }\end{array}$} & $\begin{array}{l}\text { Mean } \\
\text { Remark }\end{array}$ & \multicolumn{2}{|c|}{$\begin{array}{l}\text { Mean } \\
\text { Remark }\end{array}$} \\
\hline 1. & $\begin{array}{l}\text { Deliver Environmental } \\
\text { Justice to the people }\end{array}$ & 4.20 & $\mathrm{HE}$ & 1.96 & LE & $\begin{array}{l}2.31 \\
\mathrm{LE}\end{array}$ & 2.82 & $\mathrm{ME}$ \\
\hline & $\begin{array}{l}\text { Encourage citizens to } \\
\text { institute legal actions } \\
\text { against polluters }\end{array}$ & 4.20 & $\mathrm{HE}$ & 2.72 & ME & $\begin{array}{l}2.69 \\
\mathrm{ME}\end{array}$ & 3.20 & $\mathrm{ME}$ \\
\hline 3. & $\begin{array}{l}\text { Advocate for new } \\
\text { policies related to } \\
\text { environmental protection }\end{array}$ & 4.16 & $\mathrm{HE}$ & 2.48 & LE & $\begin{array}{l}2.24 \\
\mathrm{LE}\end{array}$ & 2.96 & $\mathrm{ME}$ \\
\hline 4. & $\begin{array}{l}\text { Provide mentorship } \\
\text { opportunities on } \\
\text { environmental law and } \\
\text { litigation to junior } \\
\text { Lawyers }\end{array}$ & 4.32 & $\mathrm{HE}$ & 2.24 & LE & $\begin{array}{l}2.42 \\
\mathrm{LE}\end{array}$ & 2.99 & $\mathrm{ME}$ \\
\hline 5. & $\begin{array}{l}\text { Advocate for the } \\
\text { provision of } \\
\text { environmental court }\end{array}$ & 3.68 & $\mathrm{HE}$ & 2.40 & LE & $\begin{array}{l}2.30 \\
\mathrm{LE}\end{array}$ & 2.79 & $\mathrm{ME}$ \\
\hline 6. & $\begin{array}{l}\text { Encourage the inclusion } \\
\text { of environmental law and } \\
\text { litigation in the law } \\
\text { curriculum }\end{array}$ & 3.80 & $\mathrm{HE}$ & 2.32 & LE & $\begin{array}{l}2.21 \\
\mathrm{LE}\end{array}$ & 2.77 & $\mathrm{ME}$ \\
\hline 7. & $\begin{array}{l}\text { Provide appropriate } \\
\text { training to boost lawyers } \\
\text { competence in } \\
\text { environmental litigation }\end{array}$ & 3.52 & $\mathrm{HE}$ & 2.44 & $\mathrm{LE}$ & $\begin{array}{l}2.43 \\
\mathrm{LE}\end{array}$ & 2.79 & $\mathrm{ME}$ \\
\hline 8. & $\begin{array}{l}\text { Encourage the public } \\
\text { interest litigation by } \\
\text { reducing the bottlenecks } \\
\text { in the locus standi }\end{array}$ & 4.40 & $\mathrm{HE}$ & 2.24 & LE & $\begin{array}{l}2.25 \\
\mathrm{LE}\end{array}$ & 2.96 & $\mathrm{ME}$ \\
\hline 9. & $\begin{array}{l}\text { Enforce of constitutional } \\
\text { rights of the people as it } \\
\text { relates to environmental }\end{array}$ & 3.92 & $\mathrm{HE}$ & 2.20 & $\mathrm{LE}$ & $\begin{array}{l}2.42 \\
\mathrm{LE}\end{array}$ & 2.84 & $\mathrm{ME}$ \\
\hline
\end{tabular}


sustainability

10. Create awareness of 3.64 HE 2.08 LE 2.18

$2.63 \quad \mathrm{ME}$ environmental law among the populace

\section{Grand Mean} 3.98 2.31

LE 2.42 LE

\section{$2.90 \quad$ ME}

As displayed in Table 2, the overall grand mean of 2.90 indicates that legal practitioners perform their environmental protection roles in Anambra to a moderate extent. The grand mean for legal practitioners (3.98), environmentalist (2.31) and other professionals (2.42) indicate that legal practitioners rated the extent to which they perform their environmental protection roles in Anambra to a high extent while environmentalists and other professionals rated the roles as being performed to a low extent.

The item-by-items analysis shows that legal practitioners rated all the 10 listed roles as being played to a high extent with their mean ratings ranging from 3.52 to 4.40. Environmentalists and other professionals however rated only item 2 (Encouraging citizens to institute legal actions against polluters) with mean ratings 2.72 and 2.69 as being performed to a moderate extent while the remaining 9 items were rated as being performed to a low extent with their mean ratings ranging from 1.96 to 2.48 for environmentalists and from 2.18 to 2.43 for other professionals.

\subsection{CONCLUSION}

The legal practitioner is a crucial partner in promoting environmental protection because their roles deter polluters ranging from individuals, industries, communities and others from polluting the environment with impunity. There is a clear indication that while the legal practitioners are of the opinion that they are doing their best, the result revealed that both the environmentalists and other professionals who actually need the services of the legal practitioners rated their performance to be very low. Appropriate training and awareness programmes are therefore recommended so that lawyers would be better grounded to discharge this onerous duty in the state.

\section{References::}

11. Amangabara, G.T. (2012) Analysis of Selected gully Erosion Control Works in Imo State.Hydrology for Disaster Management. Special Publication of the Nigerian Association of Hydrological Sciences.

12. Arambepola,N. and Iglesias.G. (2009) Effective Strategies for urban flood risk management. Asian Disaster Preparedness Center,Bangkok. www.adpc.net 
13. Egboka, B.C.E, (2009) Keynote address delivered at The Anambra State Erosion Control Summit Holding at Suncity Exclusive Hotels, Awka, on Tuesday $17^{\text {th }}$ November, 2009

14. Okoye, A.C. (2016) The Need for Integration of Waste Management Systems into Anambra State Capital Master Plan.Environmental Review;Vol.5, No 2, Pp128-133

15. Shelton, D. and Kiss, A. (2005) Judicial handbook on Environmental Law, ISBN: 92-807-2555-6, Earth Print Limited Orders Dpt. United Kingdom, (C) United Nations Environment Programme,

16. The Lawyers Role in the Society (http://www.thelawyerschronicle.com/the-lawyers-role-in-thesociety/) retrieved on 23/02/17 